\title{
INIERNATIONAL LEGAL MATERIALS
}

\section{CURRENT DOCUMENTS}

MARCH 1963

The American Society of International Law 2223 Massachusetts Avenue, N.W.

WaSHington 8, D.C. 
Editor

H. C. L. Merillat

Assistant Editor

Richard W. Edwards, Jr.

Production

Ellen Morris McClellan

Editorial Advisory Committee

Stanley D. Metzger

Arthur S. Miller

Walter S. Surrey 
International Legal Materials is a collection of current official documents designed to meet needs for up-todate information by scholars, practicing lawyers, legal advisers to government agencies and corporations, national and international officials, and others concerned with the legal aspects of public and private international dealings. The documents fall into two main groups: current materials not available in more permanent collections until a later date; and recent materials, likely to be of interest to a broad group of readers, that are not readily available in any other form in most law libraries.

The term international 1 aw is interpreted broadly for the purposes of this publication. Some of the materials may be of a kind normally classified under other rubrics, such as foreign law, comparative law, conflicts of law, constitutional law, international organization, and the like. The main criterion in selecting materials is that the document be of substantial interest to a large number of legal scholars, practicing lawyers, and officials dealing with public and private international matters. It is recognized that these interests may vary considerably among users of the publication in the United states and elsewhere.

Technical matters covered by more highly specialized publications, such as tax law in the United states and elsewhere, are normally excluded. Articles, speeches, commentaries, and reports by individuals and private organizations are also excluded.

We try to reproduce the original documents whenever possible within our deadlines. In some instances, however, the documents appear in typewritten form -- for example, when the material is not yet available in an official printing or when excerpts are used. 
Colombo Conference Proposals on Indian-Chinese

Border Dispute . . . . . . . . . . . . . . .

France and Gernany: Treaty of Cooperation . . . . . 229

Organization of Central American States: Charter. • . 235

Organisation for Economic Cooperation and Develop-

ment: Draft Convention on the Protection of

Foreign Property . . . . . . . . . . . . . . 241

Panama and United States: Agreement on Certain

Procedural Matters in Canal Zone . . . . . . . . 268

United Kingdom and U.S.S.R.: Cultural Exchange

Agreement. . . . . . . . . . . . . . . 270

United Kingdom and United States: Statement on

Nuclear Defense Systems (Nassau Agreement) . . . . . 279

United States: Investment Guaranty Agreements:

Accession List of Agreements Concluded. . . . . 280

Venezuela-United States Agreement . . . . . . . 282

United States: List of Treaties signed But Not

Yet in Force. . . . . . . . . . . . . . . 284

United States and U.S.S.R.: Correspondence Regarding

Nuclear Test Ban Treaty. . . . . . . . . . . . 298

REPORTS

United Nations: Report of Secretary-General on

Implementation of Plan for National Reconciliation

in the Congo. . . . . . . . . . . . . . 303

United states: Institute for Defense Analyses

Report of Meeting on Verification and Response in

Disarmament Agreements (Woods Hole Summer Study) • . 320

President's Report to Congress on Activities under the Communications satellite Act. . . . 
JUDICIAL AND SIMILAR PROCEEDINGS

Page

Denmark: Litigation Concerning the Lucky Star (offshore broadcasting). . . . . . . . . . . 343

United Kingdom: Decisions of the House of Lords and High Court of Justice in Ex parte Enahoro (extradition of Nigerian political leader) . . . . . 346

United States: Decisions of the supreme Court in

McCulloch v. Sociedad Nacional and related cases (application of U.S. labor legislation to foreign crews and foreign vessels)......... . 350

Proceedings in the supreme court in the Sabbatino case. . . . . . . . . . 366

\section{LEGISLATION AND REGULATIONS}

European Economic Community: Regulation on Registration of Two-Party Trade Agreements. . . . . . .

Communiqués on Exclusive Representation Contracts and Patent License Agreements. . . . . 375

United States: Amendments to Federal Rules of Civil Procedure (new provisions regarding international civil procedure). . . . . . . . . . 382

Regulation on Cuban Shipping. . . . . . . . 384

Suspension of Aid to Ceylon: Statements of United States Government and Government of Ceylon................ . 386

OTHER DOCUMENTS

United States: Articles of Incorporation of the Communications Satellite Corporation . . . . . . .

NOTICE OF OTHER RECENT DOCUMENTS (not reprinted). . . . . 